\title{
Zerconid mites (Acari, Zerconidae) from eastern parts of Aydın Province (Turkey), with description of Zercon karacasuensis sp. nov.
}

\author{
Davut Rıza BULUT 1 (1D), Raşit URHAN ${ }^{1}$ (D), Mehmet KARACA ${ }^{2,3}$ (i) \\ ${ }^{1}$ Department of Biology, Faculty of Science and Arts, Pamukkale University, Denizli, Turkey \\ ${ }^{2}$ Department of Electronic and Automation, Denizli Vocational School of Technical Sciences, Pamukkale University, Denizli, \\ Turkey \\ ${ }^{3}$ Corresponding author: karacamehmet@pau.edu.tr
}

Received: 7 April 2021

Accepted: 3 June 2021

Available online: 31 July 2021

ABSTRACT: Species diversity of zerconid mites was investigated in Buharkent, Karacasu and Kuyucak counties of Aydın province during February 2019 until February 2020. Seven species of the family Zerconidae were found in the research area, two of which belong to the genus Prozercon and remaining five species belong to the genus Zercon. A new species, $Z$. karacasuensis sp. nov., was collected from pine habitats (Pinus sp.) and described. In addition, altitute and habitat preferences of all zerconid mites collected from the research area, were given.

Keywords: Mesostigmata, new species, preference, Buharkent, Karacasu, Kuyucak.

Zoobank: http://zoobank.org/267CE1FD-CA43-4482-A06B-AC1C2BEA1316

\section{INTRODUCTION}

Members of the family Zerconidae constitute a large group of soil-inhabiting mites in the order Mesostigmata. However, all records of genera and species of zerconids have been only known from the Holarctic region. In terms of the species richness of zerconid mites, Turkey is one of the well studied countries. Although, two genera (Prozercon and Zercon) and 130 species from the country have been recorded, there are many areas that have not been studied hitherto (Urhan and Karaca, 2019, 2020; Urhan et al., 2020a,b; Karaca, 2021; Keçeci et al., 2021). Systematics and ecological researches are still ongoing on this family both in Turkey and the other countries in Northern hemisphere. Therefore, new occurrences of zerconid mites are being increased day by day, especially with local systematic studies in these areas (Marchenko, 2018, 2019, 2021; Kaczmarek et al., 2020; Moghimi et al., 2021).

Aydin, one of the provinces in the Aegean region, includes 17 counties. Conditions of the Mediterranean climate and topographical structure caused the development of two separate plant communities (maquis and forest) in Aydın and its surroundings. In the present study, three counties (Buharkent, Karacasu and Kuyucak) of Aydın Province were selected for the reveal of species diversity of zerconid mites. According to literature records, no studies about zerconid mites have been performed in these counties so far. Also, it is aimed that to research about altitudinal and habitat preferences of zerconids as well as the species diversity.

For these purposes, species diversity of zerconid mites in Buharkent, Karacasu and Kuyucak counties were investigated. A species list for the family found in the research area were presented, their previous records were noted, and altitudinal and habitat preferences of the species were revealed. In addition, description of a new species, Zercon karacasuensis sp. nov. was given.

\section{MATERIALS AND METHODS}

Mite specimens were collected from different localities (especially from forestland areas) in Buharkent, Karacasu and Kuyucak counties, Aydın Province, between February 2019 and February 2020. Soil, litter and moss samples were taken from 98 sites, and totally 407 samplings were made in the research area. The Garmin GPSmap 62s was used for taking information of sampling sites (coordinates and altitudes). All collected materials were carried to the laboratory and later processed using Berlese-Tullgren funnel with 25 Watt fluorescent bulb for one week.

Zerconid mites were extracted using a stereo microscope (Nikon SMZ 745T), then cleared in 60\% lactic acid and transferred to glycerine medium. A light microscope (Olympus CX41) was used for identification of zerconids. The Olympus DP25 camera integrated into light microscope was used to transfer living images to the computer system. Illustrations of specimens of Zercon karacasuensis sp. nov. were made by pencil drawing. The DP2-BSW (ver.2.1) software was used for measurement of various body parts and setae of the species. The holotype and paratypes of the new species, as well as the other zerconid specimens were deposited in the Acarology Laboratory of the Department of Biology, Faculty of Science and Arts, Pamukkale University, Denizli, Turkey.

Terminology of idiosomal setation follows Lindquist and Evans (1965), with modifications for the caudal region as given by Lindquist and Moraza (1998). Terminology of idiosomal adenotaxy and poroidotaxy follows that of Johnston and Moraza (1991). All measurements were given as micrometers $(\mu \mathrm{m})$. Abbreviations of DN and PN were used for deutonymph and protonymph specimens, respectively. 


\section{RESULTS}

After examination of zerconid mites collected from the research area, two Prozercon and five Zercon species were identified. All the species were listed below, and some information about each species, e.g. numbers and localities of examined specimens, distributions of the species in Turkey and the world, altitude and habitat preferences of the specimens were given in alphabetical order herein. With the new species, the number of zerconid mites known from Turkey has increased to 131.

Family Zerconidae Canestrini, 1891

Genus Prozercon Sellnick, 1943

Type species: Zercon fimbriatus C. L. Koch, 1839

Prozercon demirsoyi Urhan and Ayyıldız, 1996

Materials examined: One male: soil and litter samples under common fig tree (Ficus carica), 3754'10.68" N, $28^{\circ} 32 ' 37.50^{\prime \prime}$ E, $94 \mathrm{~m}$ a.s.l., Obam roadhouse, vicinity of Pamukören neighborhood (Kuyucak), 3 February 2019. Three females: soil and litter samples under rockrose (Cistus sp.), 38²'53.76" N, 28³8'25.68" E, 860 m a.s.l., vicinity of Taşoluk neighborhood (Kuyucak), 6 October 2019. Seven females and four males: soil and litter samples under black pine tree (Pinus nigra), 37059'16.62" N, $28^{\circ} 41^{\prime} 1.08^{\prime \prime}$ E, 450 m a.s.l., Karacaören graveyard (Karacasu), 7 October 2019. Four females and two males: soil and litter samples under kermes oak tree (Quercus coccifera), 37²8'52.26" N, 28³9'17.16" E, 755 m a.s.l., vicinity of Karacaören neighborhood (Karacasu), 7 October 2019. Four females and two males: moss samples, 3759'16.62" N, 2841'1.08" E, 450 m a.s.l., Gelenbe neighborhood (Buharkent), 22 January 2020. Five females: soil and litter samples under kermes oak tree (Quercus coccifera), 3758'39.96" N, 28³6'56.04" E, $701 \mathrm{~m}$ a.s.l., Dereköy neighborhood (Kuyucak), 22 January 2020. Three females and four males: soil and litter samples under Mount Tabor oak tree (Quercus ithaburensis), 37058'45.96" N, 28³6'46.38" E, 771 m a.s.l., Dereköy neighborhood (Kuyucak), 22 January 2020. Five females and one male: soil and litter samples under Mount Tabor oak tree (Quercus ithaburensis), 3758'25.62" $\mathrm{N}$, $28^{\circ} 40^{\prime} 31.14 "$ E, $377 \mathrm{~m}$ a.s.l., Feslek neighborhood (Buharkent), 22 January 2020.

Turkish distribution: Artvin (Urhan and Ayyıldız, 1996), Giresun (Karaca and Urhan, 2015), İstanbul (Duran and Urhan, 2017) and Aydın (present study).

Known distribution: Turkey (Urhan and Ayyıldız, 1996).

\section{Prozercon yavuzi Urhan, 1998}

Materials examined: Two females: soil and litter samples under olive tree (Olea europaea), 3754'45.84" $\mathrm{N}$, $28^{\circ} 34^{\prime} 46.26^{\prime \prime}$ E, $103 \mathrm{~m}$ a.s.l., vicinity of Horsunlu neighborhood (Kuyucak), 3 February 2019. Four females: soil and litter samples under kermes oak tree (Quercus coccifera) and Turkish pine tree (Pinus brutia), 37 $54^{\prime} 20.22^{\prime \prime}$ $\mathrm{N}, 28^{\circ} 29^{\prime} 40.50^{\prime \prime}$ E, $83 \mathrm{~m}$ a.s.l., Buharkent-Karacasu-
Kuyucak road junction (Kuyucak), 3 February 2019. Three females: soil and litter samples under Aleppo oak tree (Quercus infectoria), 37²4'20.46" N, 28³7'9.90" E, $667 \mathrm{~m}$ a.s.l., Yazır neighborhood (Karacasu), 7 October 2019. One female: moss samples, $37^{\circ} 40^{\prime} 31.14^{\prime \prime} \mathrm{N}$, $28^{\circ} 38^{\prime} 32.64^{\prime \prime}$ E, $638 \mathrm{~m}$ a.s.l., vicinity of Yazır neighborhood (Karacasu), 7 October 2019.

Turkish distribution: Muğla (Urhan, 1998), Denizli, Aydın (Karaca, 2015), İstanbul (Duran and Urhan, 2017) and Balıkesir (Karaca, 2021).

Known distribution: Turkey (Urhan, 1998) and Greece (Ujvári, 2008, 2011).

Genus Zercon C. L. Koch, 1836

Type species: Zercon triangularis C. L. Koch, 1836

\section{Zercon colligans Berlese, 1920}

This species was the most abundant zerconid species in terms of number of individuals in the study area.

Materials examined: 187 females, 146 males, 79 DN and 40 PN: soil, litter and moss samples under various plants (see Table 4), 3757'20.70" N, 2845'38.52" E, $151 \mathrm{~m}$ a.s.l., Savclllı neighorbood (Buharkent), 2 February 2019. 140 females, 82 males, $45 \mathrm{DN}$ and $24 \mathrm{PN}$ : soil, litter and moss samples under various plants (see Table 4), 3756'18.66" N, 2848'21.72" E, 203 m a.s.l., Kizildere neighorbood (Buharkent), 2 February 2019. 156 females, 112 males, 56 DN and 21 PN: soil, litter and moss samples under various plants (see Table 4), 3758'35.94" $\mathrm{N}$, $28^{\circ} 48^{\prime} 24.66^{\prime \prime}$ E, $361 \mathrm{~m}$ a.s.l., vicinity of Kizlldere neighorbood (Buharkent), 2 February 2019. 61 females, 30 males and 13 DN: soil, litter and moss samples under

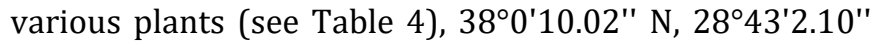
E, $839 \mathrm{~m}$ a.s.l., Muratdağı neighorbood (Buharkent), 5 October 2019. 63 females, 23 males, 16 DN and four PN: soil, litter and moss samples under various plants (see Table 4), 3858'25.62" N, 2840'31.14" E, 377 m a.s.l., Feslek neighorbood (Buharkent), 22 January 2020. 408 females, 233 males, $123 \mathrm{DN}$ and 75 PN: soil, litter and moss samples under various plants (see Table 4), 3709'40.86" N, 28³3'59.58' E, 206 m a.s.l., vicinity of Bahçeköy neighorbood (Karacasu), 4 February 2019. 129 females, 74 males, 68 DN and 35 PN: soil, litter and moss samples under various plants (see Table 4), 3704'58.50" N, 28³7'6.36" E, 366 m a.s.l., Kuyucak-Karacasu road junction (Karacasu), 4 February 2019. 249 females, 183 males, $110 \mathrm{DN}$ and $53 \mathrm{PN}$ : soil, litter and moss samples under various plants (see Table 4), 3742'41.64" $\mathrm{N}$, $28^{\circ} 43^{\prime} 48.78^{\prime \prime}$ E, 536 m a.s.l., vicinity of Aphrodisias Ancient City, Geyre graveyard (Karacasu), 4 February 2019. 161 females, 184 males, 92 DN and 53 PN: soil, litter and moss samples under various plants (see Table 4), 3751'25.92" N, 28³9'33.42" E, $464 \mathrm{~m}$ a.s.l., vicinity of Aksaz neighorbood (Karacasu), 27 June 2019. 180 females, 95 males, $75 \mathrm{DN}$ and $27 \mathrm{PN}$ : soil, litter and moss samples under various plants (see Table 4), 3749'38.82" N, 28³4'23.22" E, 205 m a.s.l., vicinity of Bahçeköy neighorbood (Karacasu), 22 January 2020. 249 females, 179 males, 118 DN and 70 PN: soil, litter and moss samples 
under various plants (see Table 4), 3754'10.68" $\mathrm{N}$, $28^{\circ} 32 ' 37.50^{\prime \prime}$ E, $94 \mathrm{~m}$ a.s.l., Obam roadhouse, vicinity of Pamukören neighborhood (Kuyucak), 3 February 2019. 521 females, 289 males, $75 \mathrm{DN}$ and $41 \mathrm{PN}$ : soil, litter and moss samples under various plants (see Table 4), 3753'19.02" N, 28³8'53.64" E, 170 m a.s.l., Yamalak neighborhood (Kuyucak), 3 February 2019. 161 females, 133 males, 76 DN and 51 PN: soil, litter and moss samples under various plants (see Table 4), 3752'15.96" $\mathrm{N}$, $28^{\circ} 39^{\prime} 27.48^{\prime \prime}$ E, $254 \mathrm{~m}$ a.s.l., vicinity of Yamalak and Aksaz neighborhoods (Kuyucak), 3 February 2019. 101 females, 32 males, 17 DN and two PN: soil, litter and moss samples under various plants (see Table 4), 38 $57^{\prime} 4.20^{\prime \prime} \mathrm{N}$, $28^{\circ} 36^{\prime} 46.92 "$ E, $424 \mathrm{~m}$ a.s.l., Kurtuluş neighborhood (Kuyucak), 22 January 2020.

Turkish distribution: Afyonkarahisar, Artvin, Aydın, Balıkesir, Çanakkale, Denizli, Edirne, Erzurum, Giresun, İstanbul, Kırklareli, Kütahya, Tekirdağ and Uşak (Karaca, 2015, 2021; Karaca and Urhan, 2016; Urhan and Duran, 2019).

Known distribution: Austria, France, Iran, Ireland, Italy, Russia, Sweden, Swiss and Turkey (Karaca and Urhan 2016; Karaca et al., 2017; Karaca, 2021).

\section{Zercon cretensis Ujvári, 2008}

Materials examined: 36 females, 21 males and $30 \mathrm{DN}$ : soil and litter samples under Turkey oak tree (Quercus cerris), olea tree (Olea europaea), garland thorn (Paliurus spinachristi) and rockrose (Cistus sp.), 3744'58.50" N, $28^{\circ} 37^{\prime} 6.36^{\prime \prime}$ E, 366 m a.s.l., Kuyucak-Karacasu road junction (Karacasu), 4 February 2019. Five females, two males and three DN: soil and litter samples under juniper tree (Juniperus sp.), 37²4'18.06" N, 28³7'23.40" E, 355 m a.s.l., Göçükbaşı neighorbood (Karacasu), 4 February 2019. One male: soil and litter samples under Turkish pine tree (Pinus brutia), 3742'27.24" N, 28³6'40.98" E, $628 \mathrm{~m}$ a.s.l., vicinity of Yazır neighorbood (Karacasu), 4 February 2019. Four females and three males: moss sample, $37^{\circ} 51^{\prime} 34.44^{\prime \prime} \mathrm{N}, 28^{\circ} 40^{\prime} 0.72^{\prime \prime}$ E, $383 \mathrm{~m}$ a.s.l., vicinity of Aksaz and Kayabaşı neighorboods (Kuyucak), 6 October 2019.

Turkish distribution: İstanbul (Duran and Urhan, 2017) and Aydin (present study).

Known distribution: Greece (Ujvári, 2008) and Turkey (Duran and Urhan, 2017).

\section{Zercon denizliensis Urhan, 2011}

Materials examined: 12 females, five males and seven DN: soil and litter samples under rockrose (Cistus sp.) and garland thorn (Paliurus spina-christi), 37044'58.50" $\mathrm{N}$, $28^{\circ} 37^{\prime} 6.36^{\prime \prime}$ E, 366 m a.s.l., Kuyucak-Karacasu road junction (Karacasu), 4 February 2019. Five females, two males and three DN: soil and litter samples under juniper tree (Juniperus sp.), 37²4'18.06" N, 28³7'23.40" E, 355 m a.s.l., vicinity of Göçükbaşı neighorbood (Karacasu), 4
February 2019. Four females and three males: moss samples, 3751'34.44' N, 2840'0.72' E, 383 m a.s.l., vicinity of Aksaz neighorbood (Kuyucak), 6 October 2019. One male: soil and litter samples under Turkish pine tree (Pinus brutia), 37²2'27.24" N, 28³6'40.98' E, $628 \mathrm{~m}$ a.s.l., vicinity of Yazır neighorbood (Karacasu), 7 October 2019. Three males: soil and litter samples under Aleppo oak tree (Quercus infectoria), 37041'20.46" N, 28³7'9.90" E, $667 \mathrm{~m}$ a.s.l., Yazır neighorbood (Karacasu), 7 October 2019. 10 females, five males and six DN: moss samples, 370'31.14" N, 28³8'32.64" E, 638 m a.s.l., vicinity of Yazır neighorbood (Karacasu), 7 October 2019. Nine females and one male: soil and litter samples under rockrose (Cistus sp.) and Mount Tabor oak tree (Quercus ithaburensis), 3758'25.62" N, 2840'31.14" E, 377 m a.s.l., Feslek neighorbood (Buharkent), 22 January 2020. Six females and three males: soil and litter samples under Turkish pine tree (Pinus brutia), 37050'17.28" $\mathrm{N}$, $28^{\circ} 34^{\prime} 34.74$ " E, 193 m a.s.l., Yenice neighorbood (Karacasu), 22 January 2020. Two males: soil and litter samples under kermes oak tree (Quercus coccifera), 37²9'18.36" N, 28³4'33.00" E, 203 m a.s.l., Çamköy neighorbood (Karacasu), 22 January 2020.

Turkish distribution: Denizli (Urhan, 2011), Afyonkarahisar, Kütahya, Uşak (Urhan and Duran, 2019), Balıkesir (Karaca, 2021) and Aydın (present study).

Known distribution: Turkey (Urhan, 2011).

\section{Zercon huseyini Urhan, 2008}

Materials examined: Four females, three males and one DN: soil and litter samples under kermes oak tree (Quercus coccifera), 3758'35.94" N, 2848'24.66" E, $361 \mathrm{~m}$ a.s.l., vicinity of Kizıldere neighorbood (Buharkent), 2 February 2019. One female: soil and litter samples under olive tree (Olea europaea), 3757'47.64" N, 2848'36.84" E, 256 m a.s.l., vicinity of Kızıldere neighorbood (Buharkent), 2 February 2019. Seven females and one male: soil and litter samples under sage-leaved rockrose (Cistus salviifolius), 3758'27.18" N, 2848'8.16" E, 415 m a.s.l., vicinity of Kizlldere neighorbood (Buharkent), 2 February 2019. Eight females, three males and two DN: soil and litter samples under Turkish pine tree (Pinus brutia) and rockrose (Cistus sp.), 37²46'24.54" N, 28³7'5.04" E, 350 $\mathrm{m}$ a.s.l., Güzelköy neighorbood (Karacasu), 7 October 2019. Two females: soil and litter samples under oleasterleafed pear tree (Pyrus elaeagrifolia), 37²51'11.52" $\mathrm{N}$, $28^{\circ} 34^{\prime} 45.24^{\prime \prime}$ E, 219 m a.s.l., Bașaran neighorbood (Karacasu), 22 January 2020. Three females and two males: soil and litter samples under black pine tree (Pinus nigra), 38³'20.52" N, 28³7'25.26" E, 894 m a.s.l., Musakolu neighorbood (Kuyucak), 22 January 2020.

Turkish distribution: Denizli (Urhan, 2008), Afyonkarahisar, Kütahya, Uşak (Urhan and Duran, 2019) and Aydın (present study).

Known distribution: Turkey (Urhan, 2008). 


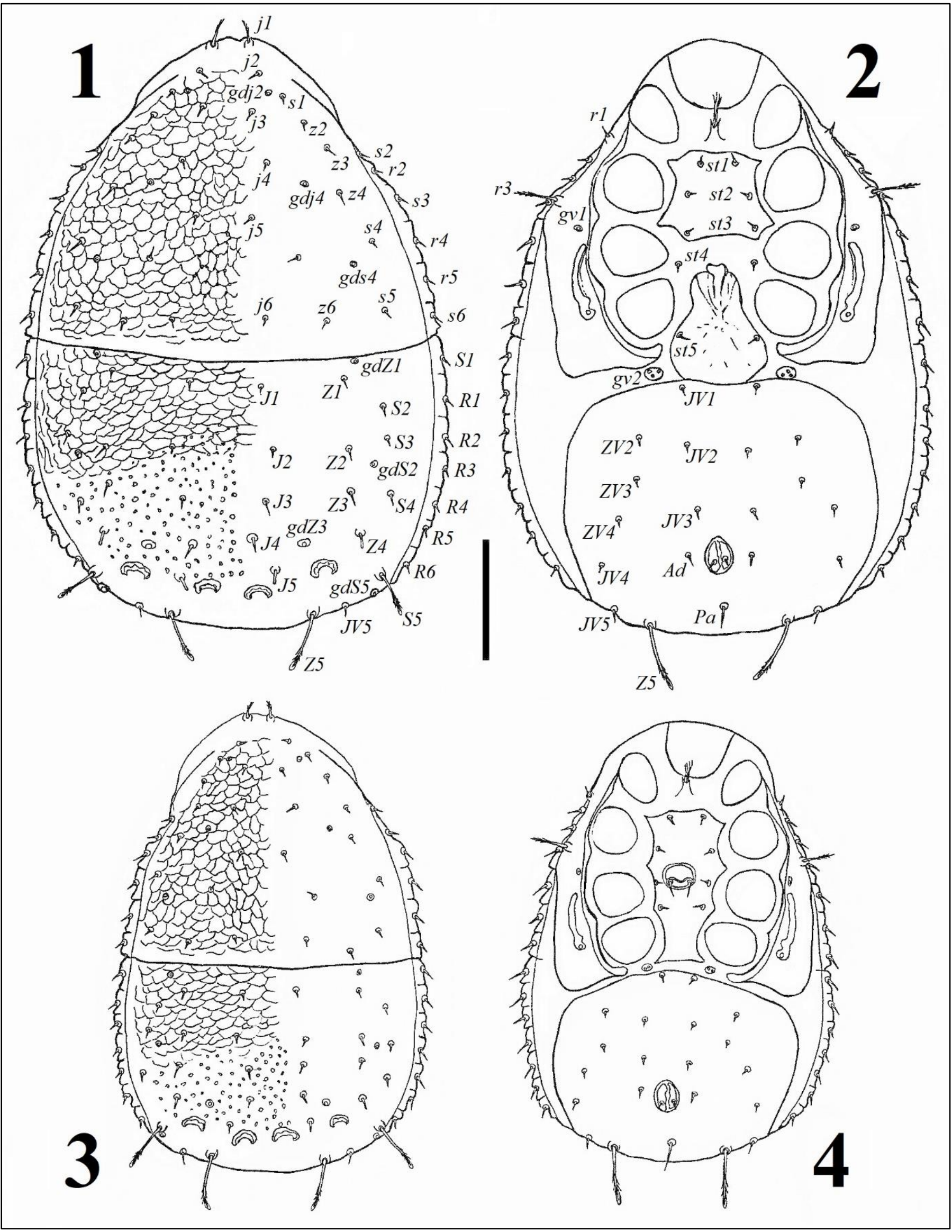

Figures 1-4. Zercon karacasuensis sp. nov. 1. Dorsal view of holotype female, 2. Ventral view of holotype female, 3. Dorsal view of male, 4. Ventral view of male. Scale bar 100. 


\section{Zercon karacasuensis sp. nov. (Figures 1-4)}

Zoobank: http:/zoobank.org/361001AE-0C37-4BB08A61-ECEB1B52D081

Type material. Holotype (female), soil and litter samples under Turkish pine tree (Pinus brutia), 37 $47^{\prime} 15.90^{\prime \prime} \mathrm{N}$, $28^{\circ} 37^{\prime} 39.30^{\prime \prime}$ E, 459 m a.s.l., vicinity of Dereköy and Güzelköy neighorboods, Karacasu County, Aydın Province, 7 October 2020. Paratypes: One female, one male, same data as holotype.

Diagnosis. Anterior margin of ventrianal shield with one pair of setae (JV1). All podonotal setae short, smooth and needle-like (except seta j1). Seta $j 1$ slightly elongated, finely barbed apically. Great majority of opisthonotal setae short, smooth and needle-like. Setae Z5 and S5 longer than other opisthonotal setae, finely barbed with hyaline endings. Pores $g d S 2$ located between setae $Z 2$ and $S 3$, gdZ3 located between setae $J 4$ and Z4. Dorsal cavities distinct and strongly developed. Podonotum and anterior margin of opisthonotum covered with tile-like pattern, mid-area to posterior margin of opisthonotum covered by irregular punctate pattern.

Female (Figs 1, 2) $(\mathrm{n}=2)$. Lenghts (without gnathosoma) 437-460 and widths 310-330.

Dorsal side (Fig. 1). Twenty pairs of setae present on podonotum: setae in $j$ series with six pairs, $z$ series with five pairs, $s$ series with six pairs and $r$ series with three pairs. All of them short, equal in size, smooth and needle-like (except seta $j 1$ ). Setae $j 1$ slightly elongated, finely barbed apically. Twenty one pairs of setae present on opisthonotum: setae in $J$ series with five pairs, $Z$ series with five pairs, $S$ series with five pairs and $R$ series with six pairs. Most of opisthonotal setae short, smooth and needle-like (except setae J5, Z4-5 and S5). Setae J5 and Z4 short, but hyaline endings without finely barbed. Setae $Z 5$ and $S 5$ longer than others, finely barbed with hyaline endings and reaching to beyond of opisthonotum. None of setae in $J, Z$ and $S$ series reaching the bases of the following seta. Seta JV5 similar in length and shape to marginal $R$ setae. All marginal setae $(S 1+R 1-R 6)$ situated as vertically to lateral margin of opisthonotum. The intervals between setae $Z 5$ and $Z 5101-107$, setae $Z 5$ and JV5 26-29, respectively. Lengths of the opisthonotal setae and distances between setal bases within longitudinal $J, Z$ and $S$ rows are given in Table 1 for female and male specimens.

Pores (Fig. 1). On podonotum, pores gdj2 located on the line connecting setae $j 3-s 1$, closer to $s 1$. Pores gdj4 located on the line connecting setae $j 4-z 4$, closer to $z 4$. Pores $g d s 4$ located on the line connecting setae $s 4-s 5$, closer to $s 4$. On opisthonotum, pores $g d Z 1$ located above the insertions of setae $Z 1$. Pores $g d S 2$ located on the line connecting setae Z2-S3. Pores $g d Z 3$ located on the line connecting setae J4-Z4, closer to J4. Pores $g d S 5$ located below to the insertions of setae $S 5$.

Ventral side (Fig. 2). Chaetotaxy and shape of the peritrematal shields normal for the genus Zercon. Posterolateral tips of peritrematal shield reaching the level of setae $S 1-R 1$. Peritrematal shield with two pairs of setae $(r 1$ and $r 3$ ), seta $r 1$ short, smooth and needle-like, seta $r 3$ elongated and finely barbed apically. Peritremes similar to reverse comma. Sternal shield with three pairs of setae (st1-st3), epigynal shield with one pair of setae (st5), and one seta (st4) located between sternal and epigynal shields; all of them (st1-st5) short, smooth and needle-like. Glands gv2 present between posterior section of epigynal shield and anterior section of ventrianal shield. Ventrianal shield with nine pairs of setae (JV1-JV5, ZV2-ZV4 and $A d$ ) and one single postanal seta $(\mathrm{Pa})$; all of them short, smooth and needle-like. Seta ZV1 absent. Postanal seta as the longest on the ventrianal shield. Anterior margin of ventrianal shield with one pair of setae (JV1).

Male (Figs 3, 4) (n= 1). Lenght (without gnathosoma) 334 and width 228. Chaetotaxy of idiosoma, location of pores on idiosoma and ornamentation of dorsal shields similar to the females (except opisthonotal setae J5 and Z4). Although these setae are hyaline endings without finely barbed in female specimens, they are smooth and needle-like in male specimen. The intervals between setae Z5 and Z5 88 , setae $Z 5$ and $J V 520$, respectively.

Immature stages. Not found.

Etymology. The specific epithet 'karacasuensis' refers to the Karacasu County (Aydın Province) where the new species was collected.

Remarks. Zercon karacasuensis sp. nov. is quite similar to Z. hispanicus Sellnick, 1958, Z. kastamonuensis Urhan and Karaca, 2019 and Z. lepurus Błazsak, 1979. The morphological distinguishing characters of these four species were given in Table 2.

\section{Altitude preferences of zerconid mites in the research area}

All materials of zerconid mites were collected from suitable forestland areas at the altitude from 0 to $1200 \mathrm{~m}$ a.s.l. All sampling areas were divided according to 100 meters elevation ranges. After identification processes in the laboratory, the altitudinal distribution results of the Prozercon and Zercon species were marked in Table 3.

According to Table 3, Z. karacasuensis sp. nov. was only found at 400-500 $\mathrm{m}$ a.s.l. Zercon colligans was found at all altitudinal zones, from 0 to $1200 \mathrm{~m}$ a.s.l. Remaining species have no clear preference in terms of altitudinal ranges.

\section{Habitat preferences of zerconid mites in the research area}

All materials of zerconid species were collected from 98 sites in the research area and the following 41 habitat types, mostly tree species, were noted: alder (Alnus sp.), almond (Prunus sp.), broom (Genista sp.), chestnut (Castanea sativa), citrus (Citrus sp.), dog rose (Rosa canina), elm (Ulmus sp.), eucalypt (Eucalyptus sp.), fig (Ficus cari$c a$ ), grape (Vitis vinifera), hawthorn (Crataegus sp.), ivy (Hedera sp.), juniper (Juniperus sp.), mastic (Pistacia sp.), milkvetch (Astragalus sp.), moss (unspecified), mullein (Verbascum sp.), oaks: Aleppo oak (Quercus infectoria), 
evergreen oak $(Q$. ilex), kermes oak $(Q$. coccifera $)$, Macedonian oak (Q. trojana), Mount Tabor oak (Q. ithaburensis), Turkey oak (Q. cerris), oleander (Nerium oleander), olive (Olea europaea), pear (Pyrus sp.), pines: black pine (Pinus nigra), stone pine (Pinus pinea), Turkish pine (Pinus brutia), pomegranate (Punica granatum), poplar (Populus sp.), raspberry (Rubus sp.), rockrose (Cistus sp.), shrub (Sytrax officinalis), spurge (Euphorbia sp.), sycamore (Platanus sp.), tamarisk (Tamarix sp.), thorn (Paliurus spina-christi), vitex (Vitex agnus-castus), walnut (Juglans regia) and willow (Salix sp.). Habitat preferences of the Prozercon and Zercon species were marked in Table 4.
According to Table 4, Zercon colligans was found in samples taken from 36 different habitat types. On the other hand, Z. karacasuensis sp. nov. was found only in Turkish pine (Pinus brutia) habitat. In addition, the most richness habitats in terms of species diversity of zerconids are follow: kermes oak, moss, rockrose and Turkisk pine. Specimens belonging to five zerconid species were found in all of these habitats. In contrary of these richness habitats, no specimens of zerconid mites were found in the following habitats: citrus, dog rose, hawthorn, mullein and spurge.

Table 1. Lengths of opisthonotal setae and the distances between their insertions in J, Z, and $S$ rows of Zercon karacasuensis sp. nov.

\begin{tabular}{|c|c|c|c|c|c|c|c|c|}
\hline Setae & 우 & $\hat{\sigma}$ & Setae & 우 & $\hat{\sigma}$ & Setae & 우 & $\hat{0}$ \\
\hline$J 1$ & $10-12$ & 6 & $Z 1$ & $15-18$ & 6 & $S 1$ & $17-20$ & 9 \\
\hline$J 1-J 2$ & $51-54$ & 34 & Z1-Z2 & $60-62$ & 35 & $S 1-S 2$ & $65-72$ & 51 \\
\hline$J 2$ & $10-13$ & 6 & $Z 2$ & $15-19$ & 6 & $S 2$ & $10-14$ & 5 \\
\hline$J 2-J 3$ & $39-41$ & 20 & Z2-Z3 & 29-33 & 14 & $S 2-S 3$ & $38-41$ & 20 \\
\hline J3 & $19-22$ & 9 & Z3 & $18-24$ & 18 & S3 & $10-16$ & 5 \\
\hline$J 3-J 4$ & $29-30$ & 18 & Z3-Z4 & 36-38 & 23 & $S 3-S 4$ & $42-47$ & 28 \\
\hline$J 4$ & $18-19$ & 8 & $Z 4$ & $11-12$ & 13 & $S 4$ & $12-19$ & 5 \\
\hline J4-J5 & $28-33$ & 26 & Z4-Z5 & $59-63$ & 37 & S4-S5 & $56-57$ & 33 \\
\hline$J 5$ & $10-16$ & 9 & $Z 5$ & $12-19$ & 12 & $S 5$ & $44-48$ & 44 \\
\hline
\end{tabular}

Table 2. Morphological distinctive characters among Z. karacasuensis sp. nov., Z. hispanicus, Z. kastamonuensis and Z. lepurus.

\begin{tabular}{|c|c|c|c|c|}
\hline Characters & $\begin{array}{l}\text { Z. karacasuensis } \\
\text { sp. nov. }\end{array}$ & $\begin{array}{l}\text { Z. hispanicus } \\
\text { Sellnick, } 1958\end{array}$ & $\begin{array}{l}\text { Z. kastamonuensis } \\
\text { Urhan and Karaca, } 2019\end{array}$ & $\begin{array}{l}\text { Z. Iepurus } \\
\text { Błazsak., } 1979\end{array}$ \\
\hline Setae $r 4-r 5, s 6$ & short, smooth, needle like & short, smooth, needle like & $\begin{array}{l}\text { short, finely barbed without } \\
\text { hyaline ending }\end{array}$ & $\begin{array}{l}\text { elongated, finely barbed } \\
\text { without hyaline ending }\end{array}$ \\
\hline Seta J3 & short, smooth, needle like & $\begin{array}{l}\text { elongated, finely barbed } \\
\text { without hyaline ending }\end{array}$ & $\begin{array}{l}\text { short, finely barbed without } \\
\text { hyaline ending }\end{array}$ & short, smooth, needle like \\
\hline Setae J4-J5 & short, smooth, needle like & $\begin{array}{l}\text { elongated, finely barbed } \\
\text { without hyaline ending }\end{array}$ & $\begin{array}{l}\text { short, finely barbed with hyali- } \\
\text { ne ending }\end{array}$ & short, smooth, needle like \\
\hline Seta $Z 3$ & $\begin{array}{l}\text { short, smooth, needle like, } \\
\text { not reaching the base of } \\
\text { seta } Z 4\end{array}$ & $\begin{array}{l}\text { elongated, finely barbed } \\
\text { without hyaline ending, } \\
\text { reaching the base of seta } Z 4\end{array}$ & $\begin{array}{l}\text { short, finely barbed without } \\
\text { hyaline ending, not reaching } \\
\text { the base of seta } Z 4\end{array}$ & $\begin{array}{l}\text { short, smooth, needle-like, } \\
\text { reaching the base of seta } Z 4\end{array}$ \\
\hline Seta $Z 4$ & $\begin{array}{l}\text { short, smooth, needle like, } \\
\text { not reaching the base of } \\
\text { seta } S 5\end{array}$ & $\begin{array}{l}\text { elongated, finely barbed } \\
\text { without hyaline ending, } \\
\text { reaching the base of seta } S 5\end{array}$ & $\begin{array}{l}\text { elongated, finely barbed with } \\
\text { hyaline ending, reaching the } \\
\text { base of seta } S 5\end{array}$ & $\begin{array}{l}\text { elongated, finely barbed with } \\
\text { hyaline ending, reaching the } \\
\text { base of seta } S 5\end{array}$ \\
\hline Seta $S 4$ & $\begin{array}{l}\text { not reaching the margin of } \\
\text { opisthonotum }\end{array}$ & $\begin{array}{l}\text { not reaching the margin of } \\
\text { opisthonotum }\end{array}$ & $\begin{array}{l}\text { not reaching the margin of } \\
\text { opisthonotum }\end{array}$ & $\begin{array}{l}\text { reaching the margin of opist- } \\
\text { honotum }\end{array}$ \\
\hline Setae $S 1, R 1-R 2$ & short, smooth, needle like & short, smooth, needle like & $\begin{array}{l}\text { short, finely barbed without } \\
\text { hyaline ending }\end{array}$ & short, smooth, needle like \\
\hline Seta JV5 & short, smooth, needle like & short, smooth, needle like & $\begin{array}{l}\text { short, finely barbed without } \\
\text { hyaline ending }\end{array}$ & elongated, smooth, needle like \\
\hline
\end{tabular}

Table 3. Altitude preferences of zerconid mites in Buharkent, Karacasu and Kuyucak counties (Aydın).

\begin{tabular}{|c|c|c|c|c|c|c|c|c|c|c|c|c|}
\hline & $\frac{1}{\partial} \bar{\theta}$ & ఏ응 & ஓ్తి હે & હે & 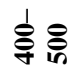 & 응 & 용 & ஓे ஓ & ஓे § & 용 & \&,$\stackrel{8}{\varrho}$ & 을 \\
\hline P. demirsoyi & + & & & + & + & & & + & + & & & \\
\hline P. yavuzi & + & + & & & & & + & & & & & \\
\hline Z. colligans & + & + & + & + & + & + & + & + & + & + & + & + \\
\hline Z. cretensis & & & & + & & & + & & & & & \\
\hline Z. denizliensis & & + & + & + & & & + & & & & & \\
\hline Z. huseyini & & & + & + & + & & & & + & & & \\
\hline
\end{tabular}

\footnotetext{
1. Altitudes in $\mathrm{m}$ a.s.l.
} 
Table 4. Habitat preferences of zerconid mites in Buharkent, Karacasu and Kuyucak counties (Aydın).

\begin{tabular}{|c|c|c|c|c|c|c|c|}
\hline & 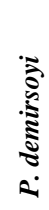 & $\underset{2}{\stackrel{N}{\Xi}}$ & 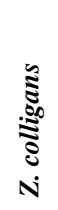 & 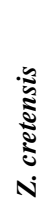 & 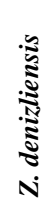 & 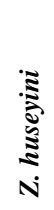 & 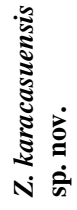 \\
\hline Alnus sp. & & & + & & & & \\
\hline Astragalus sp. & & & + & & & & \\
\hline Cistus sp. & + & & + & + & + & + & \\
\hline
\end{tabular}

Crataegus sp.

Eucaliptus sp. +

Euphorbia sp.

Ficus carica ++

Genista sp. +

Hedera sp. +

Juglans regia +

Juniperus sp.

Moss (unspecified) $++\quad+$

Nerium oleander +

\begin{tabular}{llllll} 
Olea europaea & + & + & + & + \\
Paliurus spina-christi & & + & + & + \\
\hline Pinus brutia & + & + & + & + \\
P. nigra & + & + & + & + & + \\
$P$. pinea & & + &
\end{tabular}

$\begin{array}{llll}P . & \text { nigra } & + & + \\ P . \text { pinea } & & +\end{array}$

P. pinea + +

Pistacia sp. +

Platanus sp. +

Populus sp. +

Prunus sp.

Punica granatum +

Pyrus sp. +

Quercus cerris +

$\begin{array}{llll}\text { Q. coccifera } & + & +\end{array}$

Q. ilex +

$\begin{array}{lllll}\text { Q. } \text { infectoria } & + & + & + & + \\ \text { Q. } \text { ithaburensis } & + & + & + & + \\ \text { Q. } \text { trojana } & & & + & \end{array}$

Rosa canina

\begin{tabular}{lll}
\hline Rubus sp. & + & + \\
\hline Salix sp. & + \\
\hline Sytrax officinalis & + \\
\hline Tamarix sp. & + \\
\hline Ulmus sp. & + \\
\hline Verbascum sp. & + \\
\hline Vitex agnus-castus & + \\
\hline Vitis vinifera &
\end{tabular}

\section{Authors' contributions}

Davut Riza Bulut: Investigation, collection of specimens (lead), methodology (equal), writing- original draft (supporting), preservation. Raşit Urhan: Funding acquisition, methodology (equal), project administration, supervision (lead), collection of specimens (supporting), identification, illustration. Mehmet Karaca: Data curation, formal analysis, methodology (equal), supervision (supporting), writing - original draft (lead), writing - review \& editing, collection of specimens (supporting).
Statement of ethics approval

Not applicable.

Funding

This study was financially supported by the Scientific and Technological Research Council of Turkey (TÜBİTAK) with $118 Z 101$ project number. 


\section{Conflict of interest}

No potential conflict of interest was reported by the authors.

\section{Acknowledgments}

We would like to express our sincere gratitude to TÜBİTAK for their financial support to this study. Also, we are grateful to the "Republic of Turkey Ministry of Agriculture and Forestry General Directorate of Nature Conservation and National Parks" that provided the necessary permissions for field surveys. This paper was prepared based on first author's M.Sc. thesis and summary of this study was presented as oral presentation and published as an abstract at the $2^{\text {nd }}$ Annual International Turkic World Congress on Science and Engineering (TURK-COSE 2020), which was held on 14-15 November 2020 at the L.N. Gumilyov Eurasian National University, Nur-Sultan (Kazakhstan).

\section{REFERENCES}

Duran, E.H. and Urhan, R. 2017. Zerconid mites (Acari: Zerconidae) in İstanbul with four new records for the Turkish fauna. Turkish Journal of Zoology, 41 (5): 931939.

Johnston, D.E. and Moraza, M.L. 1991. The idiosomal adenotaxy and poroidotaxy of Zerconidae (Mesostigmata: Zerconina). In: Dusbábek, F. and Bukva, V. (Eds). Modern Acarology. Academia, Prague, Czech Republic, 2: 346-356.

Kaczmarek, S., Marquardt, T. and Jangazieva, B. 2020. Zercon utemisovi sp. n. - a new species of Zerconidae (Parasitiformes, Mesostigmata) from Kazakhstan with notes on Zercon karadaghiensis Balan, 1992. International Journal of Acarology, 46 (1): 52-59. doi: 10.1080/01647954.2019.1704867

Karaca, M. 2015. Systematic studies on zerconid mites (Acari, Mesostigmata, Zerconidae) of Thrace Region (Turkey). PhD Dissertation. Department of Biology, Institute of Sciences, Pamukkale University, Denizli, Turkey, 288 pp. [In Turkish]

Karaca, M. 2021. Zerconid mites (Acari: Mesostigmata: Zerconidae) of the Kazdağı National Park, Turkey, with altitude and habitat preferences of the species. Biharean Biologist, 15(1): 6-13.

Karaca, M. and Urhan, R. 2015. The diversity of zerconid mites (Acari, Zerconidae) in Giresun province, with a new record for the Turkish fauna. Opuscula Zoologica Budapest, 46 (2): 199-209.

doi: 10.18348/opzool.2015.2.199

Karaca, M. and Urhan, R. 2016. Five new species of Zercon C. L. Koch, 1836 (Acari: Zerconidae) from northwestern Turkey. Zootaxa, 4127 (1): 31-59. doi: 10.11646/zootaxa.4127.1.2
Karaca, M., Ordoukhanian, C., Ahadiyat, A. and Urhan, R. 2017. New occurrences of zerconid mites (Acari: Zerconidae) from Iran, with checklist and a key to the Iranian species. International Journal of Acarology, 43 (8): 603-611.

doi: 10.1080/01647954.2017.1373857

Keçeci, B., Urhan, R. and Karaca, M. 2021. Mites of the genus Prozercon (Acari, Zerconidae) in Dilek Peninsula-Büyük Menderes Delta National Park (Turkey), with desription of a new species. Acarological Studies, 3 (1): 37-42.

doi: 10.47121/acarolstud.837286

Lindquist, E.E. and Evans, G.O. 1965. Taxonomic concepts in the Ascidae, with a modified setal nomenclature for the idiosoma of the Gamasina (Acarina: Mesostigmata). Memoirs of the Entomological Society of Canada, 47: 1-64.

Lindquist, E.E. and Moraza, M.L. 1998. Observations on homologies of idiosomal setae in Zerconidae (Acari: Mesostigmata), with modified notation for some posterior body setae. Acarologia, 39: 203-226.

Marchenko, I.I. 2018. A new species of Halozercon (Acari: Zerconidae) from South Siberia (Russia) with additional information on Halozercon karacholana Wiśniewski et al., 1992. Zootaxa, 4394 (3): 347-370. doi: $10.11646 /$ zootaxa.4394.3.2

Marchenko, I.I. 2019. Three new species of Halozercon (Acari: Mesostigmata: Zerconidae) from Altai Mountains in South Siberia (Russia). Zootaxa, 4568 (3): 401434.

doi: 10.11646/zootaxa.4568.3.1

Marchenko, I.I. 2021. Four new species of Halozercon (Acari: Mesostigmata: Zerconidae) from South Siberia Mountains (Russia) with a key to all known species. Zootaxa, 4941 (2): 151-185. doi: 10.11646/zootaxa.4941.2.1

Moghimi, F., Ahadiyat, A., Karaca, M., Kiadaliri, H. and Urhan, R. 2021. Description of Prozercon caspiansis sp. nov. (Acari: Mesostigmata: Zerconidae) from Iran, with descriptions of male and larva of $P$. dominiaki Błaszak, 1979. Systematic and Applied Acarology, in press.

Ujvári, Z. 2008. Zerconid mites (Acari: Mesostigmata: Zerconidae) from Crete, Greece, with description of two new species. Opuscula Zoologica Budapest, 39: 99-108.

Ujvári, Z. 2011. Six new species of Prozercon Sellnick, 1943 (Acari, Mesostigmata, Zerconidae) from Greece, with remarks on the genus. Zootaxa, 2785: 1-31. doi: 10.11646/zootaxa.2785.1.1

Urhan, R. 1998. Some new species of the family Zerconidae (Acari: Mesostigmata) from Turkey. Journal of Natural History, 32 (4): 533-543. doi: 10.1080/00222939800770291 
Urhan, R. 2008. Two new species of Zercon (Acari: Zerconidae) from Turkey. Biologia, 63 (3): 395-401. doi: 10.2478/s11756-008-0057-4

Urhan, R. 2011. Two new species of zerconid mites (Acari, Mesostigmata) from Honaz Mountain National Park (Turkey). Turkish Journal of Zoology, 35 (2): 163-174.

Urhan, R. and Ayyıldız, N. 1996. Two new species of genus Prozercon Sellnick from Turkey (Acari: Zerconidae). Genus, 7 (3): 569-580.

Urhan, R. and Duran, E.H. 2019. Zerconid mites (Acari, Zerconidae) in Inner Aegean Region, with a new record for the Turkish fauna. Zootaxa, 4568 (2): 323336.

doi: 10.11646/zootaxa.4568.2.7

Urhan, R. and Karaca, M. 2019. A new species of the genus Zercon (Acari, Mesostigmata, Zerconidae) from Kastamonu, Turkey. Acarological Studies, 1 (1): 3-10.
Urhan, R. and Karaca, M. 2020. First finding of Prozercon bulgariensis Ujvári, 2013 (Acari, Zerconidae) from Turkey. International Journal of Scientific and Technological Research, 6 (7): 91-97. doi: 10.7176/JSTR/6-07-10

Urhan, R., Duran, E.H. and Karaca, M. 2020a. Three new species of Zercon C. L. Koch, 1836 (Acari: Zerconidae) from Coastal Aegean Section of Turkey. Journal of Natural History, 54 (35-36): 2323-2341. doi: 10.1080/00222933.2020.1844328

Urhan, R., Karaca, M. and Duran, E.H. 2020b. Description of Prozercon miraci sp. nov. (Acari: Mesostigmata: Zerconidae) from Coastal Aegean Section in Turkey, with a key to the Turkish species. Acarological Studies, 2 (1): 18-23.

Edited by: Salih Doğan

Reviewed by: Three anonymous referees

Citation: Bulut, D.R., Urhan, R. and Karaca, M. 2021. Zerconid mites (Acari, Zerconidae) from eastern parts of Aydın Province (Turkey), with description of Zercon karacasuensis sp. nov. Acarological Studies, 3 (2): 73-81. 